\title{
EFFECT OF STARTER CULTURE FERMENTATION OF MILK ON THE PRODUCTION, SENSORY ATTRIBUTES AND STORAGE OF WARA (A NIGERIAN UNRIPENED SOFT CHEESE)
}

\author{
${ }^{1}$ Ajibola, W. G., ${ }^{2 *}$ Adeyemo, S. M. and ${ }^{2}$ Omafuvbe, B. O. \\ 'National Biotechnology Development Agency, Bioresources Development Centre, Owode, Nigeria. \\ ${ }^{2}$ Food and Industrial Microbiology Unit, Department of Microbiology, Obafemi Awolowo University, Ile-Ife, Nigeria. \\ Corresponding Author's E-mail: adeyemostella@gmail.com \\ (Received: $29^{\text {th }}$ June, 2020; Accepted: $29^{\text {th }}$ October, 2020)
}

ABSTRACT

\begin{abstract}
This study investigated the effect of Lactobacillus plantarum and Lactobacillus acidophilus isolated from wara, a Nigerian unripened soft cheese, on the production of starter-mediated type with improved quality and longer shelf-life. Fresh cow milk was pasteurized and inoculated with standardized cells of Lactobacillus plantarum and Lactobacillus acidophilus (singly and in combination) and incubated at $30{ }^{\circ} \mathrm{C}$ for $24 \mathrm{~h}$ to ferment. The fermented (acidified) milk was then used to produce wara using juice extract of Calotropisprocera as rennet. Viable cell counts and physicochemical properties were estimated in the fermenting milk, while organoleptic attributes of traditional and starter-mediated wara were determined following standard procedures. The wara samples were stored at $30 \pm 2{ }^{\circ} \mathrm{C}$ for 6 days during which samples were obtained daily for physicochemical and microbiological analysis. Overall, physicochemical analysis of the fermenting milk samples showed a gradual drop in $\mathrm{pH}$, increase in total titratable acidity and diacetyl level with accompanied increase in viable count. Organoleptically, there was no significant difference $(\mathrm{p}>0.05)$ between the traditional and some of the starter-mediated wara. During storage, the starter mediated wara had the lowest bacteria count and extended shelf-life.
\end{abstract}

Keywords: Wara, Starter culture, Shelf life, Sensory attributes, Fermentation.

\section{INTRODUCTION}

Wara is an unripened cheese consumed in several parts of West Africa. Wara is prepared by coagulating fresh cow milk with Sodom apple (Calotropis procera) leaf extract (Adetunji et al., 2007). Wara processing involves the use of rudimentary equipment, in many cases, starter cultures are not used and the processing conditions are not normally standardized. In an attempt to optimize the processing conditions and improve on its quality, an alternative coagulant "lemon juice" was introduced into the production of wara to reduce microbial load (Adetunji et al., 2007).

The manufacture of wara is widespread in Nigeria and a similar cheese called 'Wogachi' is made in the northern provinces of Benin republic, a French speaking country to the west of Nigeria. The Fulanis of northern Nigeria are traditionally cattle rearers and they have access to excess fresh milk (from Zebu Bos indicus cattles) used in the production of traditional milk products which include wara. Wara making, which started in the northern region of Nigeria, has spread to other parts of Nigeria such as Oyo, Ogun, Ondo, Ekiti,
Osun and the Benin Republic because of the nomadic life style of the Fulanis (Bamidele, 2006).

Milk products prepared by lactic acid fermentation (e.g. yoghurt) or a combination of this and yeast fermentation (e.g. Kefir) are called fermented or cultured milks (Teshome, 2015). Fermented milk is the collective name for products such as yoghurt, ymer, kefir, cultured buttermilk, filmjölk (Scandinavian sour milk), cultured cream and koumiss (a product based on mares' milk). The generic name of fermented milk is derived from the fact that the milk for the product is inoculated with a starter culture which converts part of the lactose to lactic acid (Teshome, 2015). Dependent on the type of lactic acid bacteria used, carbon dioxide, acetic acid, diacetyl, acetaldehyde and several other substances are formed in the conversion process, and these give the products their characteristic fresh taste and aroma. The first example of fermented milk was presumably produced accidentally by nomads (Shah and Ravula, 2000). This milk turned sour and coagulated under the influence of probiotic microorganisms. The 
bacteria are harmless, acidifying type and were not toxin-producing. There are several classes of fermented milk products which include cultured milk, dry cultured milk products, whey based cultured dairy products etc.

The bio-preservative activity of lactic acid bacteria through fermentation has been observed in some fermented products such as cereals, milk, fruits and vegetables (Adeyemi et al., 2012). The lowering of the $\mathrm{pH}$ to below 4 through acid production by the fermenting microorganisms inhibits the growth of microorganisms that cause food spoilage and food borne diseases thereby prolonging the shelf life of fermented foods (Abdel etal., 2009; Olukoya et al., 2011).

In Nigeria, due to the lack of industrial production of traditional cheese varieties, their nutritional benefits have not been fully utilized. The soft wara produced in Nigeria is at small scale level with the use of local ingredients. The vegetable rennet used for production of wara is produced from a native Sodom apple plant (Calotropis procera) which can be cultivated all year round. Therefore, there is no need for imported rennet. A better understanding of the mechanism of action of this plant rennet is required if cheese production is to be carried out on a larger scale using Sodom apple extract as the coagulant (Chipah et al., 2007).

Wara, as produced traditionally in Nigerian has a short shelf life and inconsistent quality. This study focused on the use of lactic acid bacteria with desirable biotechnological properties to produce starter-culture mediated wara with improved quality and shelf life.

\section{MATERIALS AND METHODS}

\section{Pasteurization of Cow Milk}

Fresh early morning cow milk collected at the Beef and Cattle Unit of the Teaching and Research Farm of Obafemi Awolowo University, Ile-Ife, Nigeria was dispensed in pre-sterilized conical flasks and then pasteurized for 20 seconds in a water bath set at $72^{\circ} \mathrm{C}$ (Ashaye et al., 2006).

\section{Extraction of Calotropis Procera Leave Juice}

Sodom apple (Calotropis procera) leaves were collected from Obafemi Awolowo University
Teaching and Research Farm, Ile-Ife, Osun State, Nigeria.

Fifty grams $(50 \mathrm{~g})$ of the freshly harvested Calotropis procera leaves was washed in distilled water, cut into small pieces using a sterile knife and homogenized with $150 \mathrm{ml}$ of distilled water in a sterile laboratory mortal. The mixture was sieved with a pre-sterilized muslin cloth to collect the filterate. The filterate was used as the coagulant (Akinkugbe and Onilude, 2013).

\section{Inoculum Preparation}

The cell suspension of $L$. plantarum and $L$. acidophilus with desirable biotechnological properties \{previously isolated from traditionallyproduced wara (Ajibola, 2017) $\}$ were prepared as previously described (Oyewole, 1990). The suspension was equivalent to $10^{6} \mathrm{cfu} / \mathrm{ml}$.

\section{Starter Culture Production of Wara}

The method described by Sanni et al. (1999) was employed. About $250 \mathrm{ml}$ of pasteurized fresh cow milk in replicate containers were aseptically inoculated with $12.5 \mathrm{ml}$ of the standardized cell suspension of the selected organisms as single or mixed culture (1:1), to give a cell population of $10^{6}$ cells/ml of milk (Shah, 2000). The inoculated milk was incubated at $30^{\circ} \mathrm{C}$ for $24 \mathrm{~h}$ during which samples were collected at $6 \mathrm{~h}$ intervals for microbiological and physicochemical analysis. To each portion $(250 \mathrm{ml})$ of the fermented (acidified) milk was added $2.75 \mathrm{ml}(1.3 \% \mathrm{v} / \mathrm{v})$ of the juice extract of Calotropis procera with stirring and left for $30 \mathrm{~min}$ at room temperature before heating at $85^{\circ} \mathrm{C}$ for $10 \mathrm{~min}$ to allow for formation of a firm curd and whey expulsion. The curds were poured into sterile raffia basket molds to allow the whey to drain off.

\section{Production of Traditional Wara}

About $250 \mathrm{ml}$ volumes of cow milk in conical flask was heated to approximately $50{ }^{\circ} \mathrm{C}$ in a water bath set at $85{ }^{\circ} \mathrm{C}$. It was allowed to ferment spontaneously after cooling and incubated at 30 ${ }^{\circ} \mathrm{C}$ for $24 \mathrm{~h}$. About $2.75 \mathrm{ml}$ of freshly prepared Sodom apple leave extract (coagulant) was added to the warm milk and heated until clotting began and whey expulsion was observed . Loose curd pieces were poured into raffia basket molds and 
allowed to drain (Sanni etal., 1999).

Microbiological and Physicochemical Changes during the Fermentation of Milk for Wara Production

Determination of $\mathrm{pH}$ and Total Titratable Acidity

The $\mathrm{pH}$ of the fermenting milk was measured at three hour intervals using an electronic digital $\mathrm{pH}$ meter (Hanna Instrument 8021).

Total titratable acidity (TTA) of the fermenting milk samples was determined using the titration method with phenolphthalein (1\% phenolphthalein in w/v ethanol) as end point indicator (AOAC, 2000). Ten mililitres of the sample (acidified milk) was measured and titrated against $0.1 \mathrm{M}$ sodium hydroxide solution to give a faint pink colour end point ( $\mathrm{pH}$ 8.3). One mililiter of $0.1 \mathrm{M} \mathrm{NaOH}$ was taken as equivalent to 9.008 mg of lactic acid (AOAC, 2000).

Titratable Acidity $=$

Volume (ml) of $\mathrm{NaOH} \times$ Normality of $\mathrm{NaOH} \times$ Lactic acid equivalent

Volume of sample used

\section{Determination of Diacetyl}

The amount of diacetyl produced by the lactic acid bacteria (LAB) isolates in the fermenting milk was estimated as previously described (Sanni et al.,1999). To $25 \mathrm{ml}$ of acidified milk in conical flasks was added $7.5 \mathrm{ml}$ hydroxyl amine $(0.1 \mathrm{M})$ solution which served as substrate for residual titration. The content of the flasks was then titrated with $0.1 \mathrm{~N} \mathrm{HCl}$ to a green-yellow endpoint using bromophenol blue as indicator. Each $\mathrm{ml}$ of $0.1 \mathrm{~N} \mathrm{HCl}$ is equivalent to $21.52 \mathrm{mg}$ of diacetyl.

\section{Evaluation of Changes in Viable Counts of LAB in Fermenting Milk}

The viable counts of $\mathrm{LAB}$ in the fermenting milk collected at intervals were determined following standard plate count method using De Man Rogosa Sharpe agar (MRS agar). An aliquot (5.0 $\mathrm{ml}$ ) of the fermenting milk was dispensed in $45 \mathrm{ml}$ maximum recovery diluent (MRD, $1 \mathrm{~g} / \mathrm{L}$ peptone and $8.5 \mathrm{~g} / \mathrm{L}$ of $\mathrm{NaCl}$ ) and further diluted serially up to $10^{-5}$ in MRD. Exactly $0.1 \mathrm{ml}$ of appropriately diluted sample was spread-plated on MRS agar and incubated anaerobically in a candle jar at $30^{\circ} \mathrm{C}$ for $24 \mathrm{~h}$. After incubation, the plates were observed and colonies were enumerated and expressed as cfu/ $\mathrm{ml}$ of the milk.

\section{Studies on the Storage of Starter Mediated and Traditional Wara}

The freshly produced wara (traditional and startermediated) were stored in their respective whey at ambient temperature $30 \pm 2{ }^{\circ} \mathrm{C}$ for 6 days in sterile plastic containers with covers. During the storage period, samples were withdrawn for physicochemical analysis and viable microbial counts at $24 \mathrm{~h}$ intervals.

\section{Physicochemical and Microbiological Analysis During Storage of Wara}

The wara samples collected during the 6 days' storage period at selected time intervals were monitored for viable counts of $\mathrm{LAB}$, coliforms (TCC) and total viable bacterial (TBC), $\mathrm{pH}$ and titratable acidity.

The $\mathrm{pH}$ and titratable acidity of the stored wara samples were determined as described for fermentation of milk above (AOAC, 2000).

The viable counts of $\mathrm{LAB}, \mathrm{TBC}$ and TCC were estimated using MRS agar, nutrient agar (NA) and Eosin methylene blue agar (EMBA) respectively.

Exactly $5 \mathrm{~g}$ of the wara sample was macerated in 45 $\mathrm{ml}$ of MRD up to $10^{-8}$ and $0.1 \mathrm{ml}$ of appropriately diluted sample was spread-plated on MRS agar, NA, and EMBA. The MRS agar plates were incubated anaerobically at $30{ }^{\circ} \mathrm{C}$ for $48 \mathrm{~h}$, while the NA and EMBA plates were incubated at 37 ${ }^{\circ} \mathrm{C}$ for $24 \mathrm{~h}$. The plates were observed and colonies were enumerated and expressed as $\mathrm{cfu} / \mathrm{g}$ wara sample after incubation.

\section{Sensory Analysis of Wara}

The organoleptic properties of freshly produced traditional and starter mediated wara were assessed by a panel of 15 regular consumers of wara. The samples were evaluated for colour, taste, sourness, aroma, texture and general acceptability on a 5point hedonic scale (where $5=$ Like extremely, Like $=4$, neither Like nor Dislike $=3$, Dislike $=2$ and $1=$ Dislike extremely) as previously described (Sanni et al., 1999). The data obtained were subjected to statistical analysis (Glantz, 1992). 


\section{RESULTS}

The fermentation of milk with single and combined cultures of Lactobacillus species resulted in a progressive decrease in $\mathrm{pH}$ (Table 1) and increase in the Total Titratable Acidity (Table 2) and diacetyl level (Table 3). The single and mixed starter culture fermentations showed the same pattern of gradual increase in viable counts of $\mathrm{LAB}$ as fermentation progressed (Table 4).

Table 1: Changes in pH During Fermentation of Milk Inoculated with Single and Combined Starter Cultures of Lactobacillus species

\begin{tabular}{cccc}
\hline $\begin{array}{c}\text { Fermentation } \\
\text { time (h) }\end{array}$ & L. acidophilus & L. plantarum & L. acidophilus and L. plantarum \\
\hline 0 & $6.67 \pm 0.06^{\mathrm{a}}$ & $6.67 \pm 0.06^{\mathrm{a}}$ & $6.73 \pm 0.12^{\mathrm{a}}$ \\
3 & $6.63 \pm 0.06^{\mathrm{a}}$ & $6.60 \pm 0.01^{\mathrm{a}}$ & $6.63 \pm 0.06^{\mathrm{a}}$ \\
6 & $6.53 \pm 0.06^{\mathrm{a}}$ & $6.53 \pm 0.06^{\mathrm{a}}$ & $6.50 \pm 0.06^{\mathrm{a}}$ \\
12 & $6.47 \pm 0.06^{\mathrm{a}}$ & $6.33 \pm 0.06^{\mathrm{a}}$ & $6.47 \pm 0.06^{\mathrm{a}}$ \\
18 & $5.60 \pm 0.20^{\mathrm{a}}$ & $5.60 \pm 0.00^{\mathrm{a}}$ & $5.83 \pm 0.06^{\mathrm{a}}$ \\
24 & $5.60 \pm 0.00^{\mathrm{b}}$ & $5.57 \pm 0.06^{\mathrm{b}}$ & $5.40 \pm 0.01^{\mathrm{b}}$ \\
\hline
\end{tabular}

Values are the means \pm standard deviation where $n=3$. Means with different superscripts within rows are significantly different at $\mathrm{p}<0.05$.

Table 2: Changes in Total Titratable Acidity During Fermentation of Milk Inoculated with Single and Mixed Cultures of Lactobacillus Species

\begin{tabular}{cccc}
\hline $\begin{array}{c}\text { Fermentation } \\
\text { time }(\mathrm{h})\end{array}$ & L. acidophilus & L. plantarum & L. acidophilus and L. plantarum \\
\hline 0 & $1.70 \pm 0.05^{\mathrm{a}}$ & $1.67 \pm 0.05^{\mathrm{a}}$ & $1.67 \pm 0.05^{\mathrm{a}}$ \\
3 & $1.67 \pm 0.05^{\mathrm{a}}$ & $1.70 \pm 0.05^{\mathrm{a}}$ & $1.70 \pm 0.05^{\mathrm{a}}$ \\
6 & $1.82 \pm 0.00^{\mathrm{a}}$ & $1.85 \pm 0.05^{\mathrm{a}}$ & $1.85 \pm 0.05^{\mathrm{a}}$ \\
12 & $2.06 \pm 0.05^{\mathrm{a}}$ & $2.03 \pm 0.05^{\mathrm{a}}$ & $2.03 \pm 0.05^{\mathrm{a}}$ \\
18 & $3.15 \pm 0.05^{\mathrm{a}}$ & $2.82 \pm 0.09^{\mathrm{b}}$ & $3.12 \pm 0.05^{\mathrm{a}}$ \\
24 & $3.97 \pm 0.05^{\mathrm{b}}$ & $4.22 \pm 0.05^{\mathrm{b}}$ & $4.09 \pm 0.10^{\mathrm{b}}$ \\
\hline
\end{tabular}

*Titratable acidity expressed as mg lactic acid / $\mathrm{ml}$.

Values are the means \pm standard deviation where $\mathrm{n}=3$. Means with different superscripts within each row are significantly different at $\mathrm{p}<0.05$.

Table 3: Changes in Diacetyl Level of Milk Inoculated with Single and Mixed Cultures of Isolated Lactobacillus Species

\begin{tabular}{cccc}
\hline $\begin{array}{c}\text { Fermentation } \\
\text { time }(\mathrm{h})\end{array}$ & L. acidophilus & L. plantarum & $\begin{array}{c}\text { L. acidophilus and } L . \\
\text { plantarum }\end{array}$ \\
\hline 0 & $26.94 \pm 0.46^{\mathrm{a}}$ & $27.73 \pm 0.45^{\mathrm{a}}$ & $27.73 \pm 0.45^{\mathrm{a}}$ \\
3 & $28.48 \pm 0.46^{\mathrm{a}}$ & $28.25 \pm 0.79^{\mathrm{a}}$ & $28.78 \pm 0.46^{\mathrm{a}}$ \\
6 & $32.96 \pm 0.79^{\mathrm{b}}$ & $33.49 \pm 0.46^{\mathrm{b}}$ & $31.92 \pm 0.45^{\mathrm{b}}$ \\
12 & $36.89 \pm 1.57^{\mathrm{a}}$ & $37.94 \pm 0.91^{\mathrm{a}}$ & $36.10 \pm 0.79^{\mathrm{a}}$ \\
18 & $59.64 \pm 3.93^{\mathrm{a}}$ & $65.52 \pm 1.20^{\mathrm{a}}$ & $59.91 \pm 0.91^{\mathrm{a}}$ \\
24 & $65.40 \pm 1.20^{\mathrm{b}}$ & $64.35 \pm 0.79^{\mathrm{b}}$ & $64.88 \pm 1.20^{\mathrm{b}}$ \\
\hline
\end{tabular}

Diacetyl expressed as $\mathrm{mg} / \mathrm{ml}$.

Values are the means \pm standard deviation where $n=3$. Means with different superscripts within each row are significantly different at $\mathrm{p}<0.05$. 
Table 4: Changes in Viable Count of Milk Inoculated with Single and Mixed Cultures of Lactobacillus Species

\begin{tabular}{cccc}
\hline $\begin{array}{c}\text { Fermentation } \\
\text { time }(\mathrm{h})\end{array}$ & L. acidophilus & L. plantarum & $\begin{array}{c}\text { L. acidophilus and } \\
\text { L. plantarum }\end{array}$ \\
\hline 0 & $6.04 \pm 0.04^{\mathrm{a}}$ & $6.08 \pm 0.04^{\mathrm{a}}$ & $6.06 \pm 0.06^{\mathrm{a}}$ \\
3 & $6.04 \pm 0.04^{\mathrm{b}}$ & $6.04 \pm 0.04^{\mathrm{b}}$ & $6.45 \pm 0.02^{\mathrm{a}}$ \\
6 & $8.23 \pm 0.03^{\mathrm{b}}$ & $8.23 \pm 0.03^{\mathrm{b}}$ & $7.92 \pm 0.01^{\mathrm{c}}$ \\
12 & $8.32 \pm 0.02^{\mathrm{a}}$ & $8.32 \pm 0.02^{\mathrm{a}}$ & $8.33 \pm 0.03^{\mathrm{a}}$ \\
18 & $11.12 \pm 0.04^{\mathrm{b}}$ & $11.12 \pm 0.04^{\mathrm{b}}$ & $10.99 \pm 0.01^{\mathrm{c}}$ \\
24 & $12.41 \pm 0.01^{\mathrm{b}}$ & $12.41 \pm 0.01^{\mathrm{b}}$ & $12.30 \pm 0.01^{\mathrm{c}}$ \\
\hline
\end{tabular}

Values are the means \pm standard deviation where $\mathrm{n}=3$. Means with different superscripts within each row are significantly different at $\mathrm{p}<0.05$.

Viable counts expressed in $\log \mathrm{cfu} / \mathrm{ml}$.

The $\mathrm{pH}$ and total titratable acidity of wara samples decreased and increased respectively as storage progressed (Table 5 and 6). Wara produced from $12 \mathrm{~h} \mathrm{~L}$. acidophilus fermented milk gave the highest TTA at the end of the 6 days of storage, while wara produced from $24 \mathrm{~h}$ mixed Lactobacillus species fermented milk gave the least reduction in $\mathrm{pH}$.
The stored wara samples showed the same pattern of gradual increase in TBC and TCC (Table 7 and 8). Of significant note is the high bacteria count recorded for traditionally- produced wara during storage while wara produced from milk acidified (fermented) by L. acidophilus had the least bacteria count at the end of storage period.

Table 5: Changes in $\mathrm{pH}$ of Wara During Storage

\begin{tabular}{|c|c|c|c|c|c|c|c|}
\hline \multirow{3}{*}{$\begin{array}{l}\text { Storage time } \\
\text { (days) }\end{array}$} & \multirow{3}{*}{$\begin{array}{c}\text { Control } \\
\text { G }\end{array}$} & \multicolumn{6}{|c|}{ Starter mediated wara samples } \\
\hline & & \multicolumn{3}{|c|}{ Wara from $12 \mathrm{~h}$ Acidified Milk } & \multicolumn{3}{|c|}{ Wara from $24 \mathrm{~h}$ Acidified Milk } \\
\hline & & $\mathrm{C}$ & $\mathrm{E}$ & A & $\bar{B}$ & $\mathrm{D}$ & $\mathrm{F}$ \\
\hline 0 & $6.90 \pm 0.01^{\mathrm{a}}$ & $6.37 \pm 0.06^{\mathrm{e}}$ & $6.27 \pm 0.06^{\mathrm{f}}$ & $6.37 \pm 0.06^{\mathrm{e}}$ & $5.50 \pm 0.01^{\mathrm{c}}$ & $5.77 \pm 0.06^{\mathrm{d}}$ & $5.40 \pm 0.01^{\mathrm{b}}$ \\
\hline 1 & $6.67 \pm 0.06^{\mathrm{a}}$ & $6.33 \pm 0.06^{\mathrm{f}}$ & $6.20 \pm 0.01^{\mathrm{f}}$ & $6.27 \pm 0.06^{\mathrm{f}}$ & $5.47 \pm 0.06^{\mathrm{b}}$ & $5.67 \pm 0.06^{\mathrm{d}}$ & $5.40 \pm 0.01^{\mathrm{b}}$ \\
\hline 2 & $6.37 \pm 0.06^{\mathrm{a}}$ & $5.87 \pm 0.06^{\mathrm{e}}$ & $5.73 \pm 0.06^{\mathrm{e}}$ & $5.77 \pm 0.06^{\mathrm{e}}$ & $4.80 \pm 0.10^{\mathrm{b}}$ & $5.27 \pm 0.06^{c}$ & $5.37 \pm 0.06^{\mathrm{c}}$ \\
\hline 3 & $6.60 \pm 0.01^{\mathrm{a}}$ & $5.63 \pm 0.06^{\mathrm{b}}$ & $5.37 \pm 0.06^{\mathrm{c}}$ & $5.53 \pm 0.06^{\mathrm{d}}$ & $4.47 \pm 0.06^{\mathrm{e}}$ & $5.07 \pm 0.06^{\mathrm{f}}$ & $5.23 \pm 0.06^{\mathrm{g}}$ \\
\hline 4 & $6.47 \pm 0.06^{\mathrm{a}}$ & $5.47 \pm 0.06^{\mathrm{gef}}$ & $5.33 \pm 0.06^{\mathrm{ed}}$ & $5.43 \pm 0.06^{\mathrm{fe}}$ & $4.40 \pm 0.10^{\mathrm{b}}$ & $5.07 \pm 0.06^{\mathrm{c}}$ & $5.27 \pm 0.06^{\mathrm{d}}$ \\
\hline 5 & $6.47 \pm 0.06^{\mathrm{a}}$ & $5.33 \pm 0.06^{g}$ & $5.20 \pm 0.01^{\mathrm{fe}}$ & $5.17 \pm 0.06^{\mathrm{e}}$ & $4.67 \pm 0.06^{\mathrm{b}}$ & $4.90 \pm 0.01^{\mathrm{d}}$ & $4.77 \pm 0.06^{c}$ \\
\hline 6 & $6.50 \pm 0.01^{\mathrm{a}}$ & $4.93 \pm 0.06^{\mathrm{e}}$ & $4.97 \pm 0.06^{\mathrm{e}}$ & $5.13 \pm 0.06^{\mathrm{g}}$ & $4.77 \pm 0.06^{\mathrm{d}}$ & $4.27 \pm 0.06^{c}$ & $3.90 \pm 0.10^{\mathrm{b}}$ \\
\hline
\end{tabular}

Values are the means \pm standard deviation $(n=3)$. Means with different superscript within rows are significantly different at $\mathrm{p}<0.05$

Key to sample codes:

Sample A: Wara made from milk fermented with L. plantarum and L. acidophilus for 12 hours Sample B: Wara made from milk fermented with Lactobacillus acidophilus for 24 hours Sample C: Wara made from milk fermented with Lactobacillus acidophilus for 12 hours Sample D: Wara made from milk fermented with Lactobacillus plantarum for 24 hours Sample E: Wara made from milk fermented with Lactobacillus plantarum for 12 hours Sample F: Wara made from milk fermented with L. acidophilus and L. plantarum for 24 hours Sample G: Traditionally produced wara 
Table 6: Changes in Total Titratable Acidity* of Wara During Storage

\begin{tabular}{|c|c|c|c|c|c|c|c|}
\hline \multirow{3}{*}{$\begin{array}{c}\text { Storage } \\
\text { Time (days) }\end{array}$} & \multirow{3}{*}{$\begin{array}{c}\text { Control } \\
\text { G }\end{array}$} & \multicolumn{6}{|c|}{ Starter mediated wara samples } \\
\hline & & \multicolumn{3}{|c|}{ Wara from $12 \mathrm{~h}$ fermented Milk } & \multicolumn{3}{|c|}{ Wara from $24 \mathrm{~h}$ fermented Milk } \\
\hline & & $\mathrm{C}$ & $\mathrm{E}$ & $\bar{A}$ & B & $\mathrm{D}$ & $\mathrm{F}$ \\
\hline 0 & $0.09 \pm 0.00^{\mathrm{b}}$ & $0.27 \pm 0.00^{c}$ & $0.24 \pm 0.05^{\mathrm{c}}$ & $0.24 \pm 0.05^{c}$ & $0.36 \pm 0.00^{c}$ & $0.33 \pm 0.05^{\mathrm{c}}$ & $0.30 \pm 0.05^{\mathrm{c}}$ \\
\hline 1 & $0.24 \pm 0.05^{\mathrm{b}}$ & $0.30 \pm 0.05^{\mathrm{b}}$ & $0.27 \pm 0.00^{\mathrm{b}}$ & $0.27 \pm 0.00^{\mathrm{b}}$ & $0.42 \pm 0.05^{\mathrm{b}}$ & $0.39 \pm 0.05^{\mathrm{b}}$ & $0.33 \pm 0.05^{\mathrm{b}}$ \\
\hline 2 & $0.52 \pm 0.06^{\mathrm{e}}$ & $0.33 \pm 0.05^{\mathrm{b}}$ & $0.39 \pm 0.05^{\mathrm{b}}$ & $0.33 \pm 0.05^{\mathrm{b}}$ & $0.61 \pm 0.06^{\mathrm{e}}$ & $0.52 \pm 0.06^{\mathrm{e}}$ & $0.70 \pm 0.05^{\mathrm{e}}$ \\
\hline 3 & $0.61 \pm 0.05^{\mathrm{c}}$ & $0.52 \pm 0.06^{\mathrm{c}}$ & $0.52 \pm 0.06^{\mathrm{c}}$ & $0.45 \pm 0.00^{c}$ & $0.70 \pm 0.05^{\mathrm{c}}$ & $0.61 \pm 0.05^{\mathrm{c}}$ & $0.73 \pm 0.00^{c}$ \\
\hline 4 & $0.67 \pm 0.05^{c}$ & $0.70 \pm 0.05^{\mathrm{c}}$ & $0.61 \pm 0.05^{\mathrm{c}}$ & $0.52 \pm 0.06^{\mathrm{c}}$ & $0.76 \pm 0.05^{\mathrm{c}}$ & $0.82 \pm 0.09^{c}$ & $0.79 \pm 0.05^{c}$ \\
\hline 5 & $0.73 \pm 0.00^{c}$ & $1.12 \pm 0.05^{\mathrm{a}}$ & $0.70 \pm 0.05^{\mathrm{c}}$ & $0.45 \pm 0.00^{\mathrm{b}}$ & $0.79 \pm 0.05^{\mathrm{c}}$ & $1.09 \pm 0.09^{\mathrm{a}}$ & $0.97 \pm 0.05^{\mathrm{f}}$ \\
\hline 6 & $0.73 \pm 0.09^{c}$ & $1.33 \pm 0.05^{\mathrm{a}}$ & $0.88 \pm 0.05^{\mathrm{c}}$ & $0.45 \pm 0.00^{\mathrm{b}}$ & $0.82 \pm 0.09^{c}$ & $1.06 \pm 0.05^{\mathrm{g}}$ & $0.91 \pm 0.00^{c}$ \\
\hline
\end{tabular}

*Titratable acidity is represented in $\mathrm{mg}$ lactic acid $/ \mathrm{ml}$ sample.

Values are the means \pm standard deviation $(n=3)$. Means with different superscript within rows are significantly different at $\mathrm{p}<0.05$

Key to sample codes:

Sample A: Wara made from milk fermented with L. plantarum and L. acidophilus for 12 hours

Sample B: Wara made from milk fermented with Lactobacillus acidophilus for 24 hours

Sample C: Wara made from milk fermented with Lactobacillus acidophilus for 12 hours

Sample D: Wara made from milk fermented with Lactobacillus plantarum for 24 hours

Sample E: Wara made from milk fermented with Lactobacillus plantarum for 12 hours

Sample F: Wara made from milk fermented with L. acidophilus and L. plantarum for 24 hours

Sample G: Traditionally produced wara

Table 7: Changes in Total Bacteria Count During Storage of Wara

\begin{tabular}{|c|c|c|c|c|c|c|c|}
\hline \multirow{3}{*}{$\begin{array}{l}\text { Storage time } \\
\text { (days) }\end{array}$} & \multirow{3}{*}{$\begin{array}{c}\text { Traditional wara } \\
\text { G }\end{array}$} & \multicolumn{6}{|c|}{ Starter mediated wara samples } \\
\hline & & \multicolumn{3}{|c|}{ Wara from $12 \mathrm{~h}$ fermented milk } & \multicolumn{3}{|c|}{ Wara from $24 \mathrm{~h}$ fermented milk } \\
\hline & & C & $\mathrm{E}$ & A & B & $\mathrm{D}$ & $\mathrm{F}$ \\
\hline 0 & $<1.0$ & $<1.0$ & $<1.0$ & $<1.0$ & $<1.0$ & $<1.0$ & $<1.0$ \\
\hline 1 & $6.60 \pm 0.01^{\mathrm{a}}$ & $6.17 \pm 0.02^{\mathrm{f}}$ & $6.22 \pm 0.02^{\mathrm{g}}$ & $5.85 \pm 0.01^{\mathrm{e}}$ & $3.34 \pm 0.02^{\mathrm{c}}$ & $3.51 \pm 0.02^{\mathrm{d}}$ & $3.29 \pm 0.01^{\mathrm{b}}$ \\
\hline 2 & $7.19 \pm 0.01^{\mathrm{a}}$ & $3.45 \pm 0.01^{\mathrm{b}}$ & $6.60 \pm 0.01^{c}$ & $5.43 \pm 0.02^{\mathrm{d}}$ & $6.43 \pm 0.01^{\mathrm{e}}$ & $3.95 \pm 0.01^{\mathrm{f}}$ & $3.30 \pm 0.01^{\mathrm{g}}$ \\
\hline 3 & $8.90 \pm 0.00^{\mathrm{a}}$ & $4.09 \pm 0.01^{\mathrm{d}}$ & $5.44 \pm 0.01^{\mathrm{c}}$ & $4.47 \pm 0.01^{\mathrm{b}}$ & $4.60 \pm 0.01^{\mathrm{e}}$ & $6.41 \pm 0.03^{g}$ & $5.94 \pm 0.01^{\mathrm{f}}$ \\
\hline 4 & $9.13 \pm 0.02^{\mathrm{a}}$ & $6.46 \pm 0.01^{\mathrm{b}}$ & $5.45 \pm 0.01^{\mathrm{c}}$ & $5.30 \pm 0.01^{\mathrm{d}}$ & $4.57 \pm 0.01^{\mathrm{e}}$ & $7.27 \pm 0.01^{\mathrm{f}}$ & $4.45 \pm 0.01^{\mathrm{g}}$ \\
\hline 5 & $10.66 \pm 0.01^{\mathrm{a}}$ & $3.48 \pm 0.01^{\mathrm{b}}$ & $4.32 \pm 0.02^{c}$ & $4.18 \pm 0.03^{\mathrm{d}}$ & $3.68 \pm 0.01^{\mathrm{e}}$ & $5.43 \pm 0.02^{\mathrm{f}}$ & $6.27 \pm 0.01^{g}$ \\
\hline 6 & $11.71 \pm 0.01^{\mathrm{a}}$ & $2.40 \pm 0.02^{\mathrm{b}}$ & $6.30 \pm 0.01^{\mathrm{ed}}$ & $6.28 \pm 0.02^{\mathrm{d}}$ & $3.59 \pm 0.01^{\mathrm{c}}$ & $6.34 \pm 0.02^{\mathrm{f}}$ & $6.40 \pm 0.02^{g}$ \\
\hline
\end{tabular}

Each value is the mean \pm standard deviation of experiments performed in triplicate $(n=7)$. Means with different superscript within rows are significantly different at $\mathrm{p}<0.05$

Key to sample codes:

Sample A: Wara made from milk fermented with L. plantarum and L. acidophilus for 12 hours Sample B: Wara made from milk fermented with Lactobacillus acidophilus for 24 hours Sample C: Wara made from milk fermented with Lactobacillus acidophilus for 12 hours Sample D: Wara made from milk fermented with Lactobacillus plantarum for 24 hours Sample E: Wara made from milk fermented with Lactobacillus plantarum for 12 hours Sample F: Wara made from milk fermented with L. acidophilus and L. plantarum for 24 hours Sample G: Traditionally produced wara 
Table 8: Coliform Count During Storage of Wara

\begin{tabular}{|c|c|c|c|c|c|c|c|}
\hline \multirow{3}{*}{$\begin{array}{l}\text { Storage time } \\
\quad \text { (days) }\end{array}$} & \multirow{3}{*}{$\begin{array}{l}\text { Control } \\
\qquad \text { G }\end{array}$} & \multicolumn{6}{|c|}{ Starter mediated wara samples } \\
\hline & & \multicolumn{3}{|c|}{ Wara from $12 \mathrm{~h}$ fermented milk } & \multicolumn{3}{|c|}{ Wara from $24 \mathrm{~h}$ fermented milk } \\
\hline & & $\mathrm{C}$ & $\mathbf{E}$ & $\mathbf{A}$ & B & $\mathbf{D}$ & F \\
\hline 0 & n. $d$ & n. $d$ & n. $d$ & n. $d$ & n. $d$ & n. $d$ & n. $d$ \\
\hline 1 & $2.04 \pm 0.00$ & n. d & n. $d$ & n. $\mathrm{d}$ & n. $\mathrm{d}$ & n. $d$ & n. $d$ \\
\hline 2 & $4.30 \pm 0.00^{\mathrm{a}}$ & n. d & $2.12 \pm 0.04^{\mathrm{b}}$ & n. d & n. $d$ & n. d & $2.32 \pm 0.02^{c}$ \\
\hline 3 & $6.45 \pm 0.01^{\mathrm{a}}$ & $3.40 \pm 0.02^{\text {ed }}$ & $3.30 \pm 0.00^{\mathrm{b}}$ & $3.36 \pm 0.00^{c}$ & n. $d$ & n. d & $3.38 \pm 0.02^{\mathrm{d}}$ \\
\hline 4 & $6.51 \pm 0.03^{\mathrm{a}}$ & $5.48 \pm 0.02^{\mathrm{b}}$ & $5.43 \pm 0.02^{\mathrm{c}}$ & $5.40 \pm 0.02^{\mathrm{d}}$ & $2.52 \pm 0.00^{\mathrm{e}}$ & $3.48 \pm 0.00^{\mathrm{f}}$ & $3.35 \pm 0.01^{8}$ \\
\hline 5 & $7.23 \pm 0.03^{a}$ & $5.22 \pm 0.02^{g f}$ & $5.08 \pm 0.04^{\mathrm{e}}$ & $5.18 \pm 0.03^{\mathrm{f}}$ & $3.25 \pm 0.03^{\mathrm{b}}$ & $4.47 \pm 0.02^{\mathrm{d}}$ & $4.42 \pm 0.02^{\circ}$ \\
\hline 6 & $9.01 \pm 0.01^{\mathrm{a}}$ & $5.32 \pm 0.02^{\mathrm{b}}$ & $7.30 \pm 0.00^{c}$ & $6.41 \pm 0.00^{\mathrm{d}}$ & $4.30 \pm 0.00^{\mathrm{e}}$ & $5.40 \pm 0.02^{\mathrm{f}}$ & $4.50 \pm 0.02^{8}$ \\
\hline
\end{tabular}

n. $\mathrm{d}$ : not detected within the limits of the method used. Counts are expressed as Log cfu/g.

Each value is the mean \pm standard deviation of experiments performed in triplicate $(n=7)$. Means with different superscript within rows are significantly different at $\mathrm{p}<0.05$

Key to sample codes:

Sample A: Wara made from milk fermented with L. plantarum and L. acidophilus for 12 hours Sample B: Wara made from milk fermented with Lactobacillus acidophilus for 24 hours Sample C: Wara made from milk fermented with Lactobacillus acidophilus for 12 hours Sample D: Wara made from milk fermented with Lactobacillus plantarum for 24 hours Sample E: Wara made from milk fermented with Lactobacillus plantarum for 12 hours Sample F: Wara made from milk fermented with L. acidophilus and L. plantarum for 24 hours Sample G: Traditionally produced wara

The viable cell count of $\mathrm{LAB}$ in the stored wara was not detectable until the $4^{\text {th }}$ day. On the $4^{\text {th }}$ day, count became detectable and increased significantly in all the stored samples up to the $6^{\text {th }}$ day (Table 9). Overall, there was no significant difference in the viable count of LAB between the traditional wara, wara made from milk fermented with mixed cultures of Lactobacillus species for 12 hours (A) and wara made from milk fermented with Lactobacillus plantarum for 12 hours (E) (Table 10).

Table 9: Changes in Lactic Acid Bacteria Count During Storage of Starter Mediated Wara

\begin{tabular}{cccc}
\hline Storage time (days) & L. acidophilus & L. plantarum & $\begin{array}{c}\text { L. acidophilus and } L . \\
\text { plantarum }\end{array}$ \\
\hline 0 & n. d & n. d & n. d \\
1 & n. d & n.d & n. d \\
2 & n. d & n.d & n. d \\
3 & n. d & n. d & n. d \\
4 & $1.90 \pm 0.01^{\mathrm{a}}$ & $3.52 \pm 0.01^{\mathrm{b}}$ & $4.40 \pm 0.02^{\mathrm{c}}$ \\
5 & $5.40 \pm 0.02^{\mathrm{a}}$ & $5.18 \pm 0.03^{\mathrm{b}}$ & $6.00 \pm 0.01^{\mathrm{c}}$ \\
6 & $7.50 \pm 0.02^{\mathrm{a}}$ & $7.28 \pm 0.02^{\mathrm{b}}$ & $8.30 \pm 0.01^{\mathrm{c}}$ \\
\hline
\end{tabular}

Viable counts expressed in $\log \mathrm{cfu} / \mathrm{g}$ n. $\mathrm{d}=$ not detected

Values are the means \pm standard deviation where $\mathrm{n}=3$. Means with different superscripts within each row are significantly different at $\mathrm{p}<0.05$. 
Table 10: Sensory Attributes of Traditional and Starter Produced Wara

\begin{tabular}{ccccccc}
\hline Sample code & Colour & Taste & Sourness & Aroma & Texture & $\begin{array}{c}\text { General } \\
\text { Acceptability }\end{array}$ \\
\hline A & $4.47 \pm 0.52^{\mathrm{a}}$ & $4.00 \pm 0.65^{\mathrm{a}}$ & $3.07 \pm 1.03^{\mathrm{a}}$ & $4.27 \pm 0.70^{\mathrm{a}}$ & $3.73 \pm 1.49^{\mathrm{a}}$ & $4.40 \pm 0.63^{\mathrm{a}}$ \\
B & $3.27 \pm 1.10^{\mathrm{c}}$ & $2.60 \pm 0.83^{\mathrm{a}}$ & $2.67 \pm 0.98^{\mathrm{a}}$ & $2.87 \pm 0.92^{\mathrm{c}}$ & $2.20 \pm 0.94^{\mathrm{b}}$ & $2.67 \pm 0.82^{\mathrm{b}}$ \\
C & $4.20 \pm 1.15^{\mathrm{a}}$ & $3.33 \pm 0.90^{\mathrm{a}}$ & $2.73 \pm 0.88^{\mathrm{a}}$ & $3.47 \pm 0.99^{\mathrm{c}}$ & $3.80 \pm 0.86^{\mathrm{a}}$ & $3.20 \pm 0.94^{\mathrm{b}}$ \\
D & $3.27 \pm 1.33^{\mathrm{c}}$ & $2.80 \pm 0.94^{\mathrm{a}}$ & $2.67 \pm 1.05^{\mathrm{a}}$ & $2.53 \pm 1.30^{\mathrm{c}}$ & $2.60 \pm 1.24^{\mathrm{b}}$ & $2.47 \pm 1.06^{\mathrm{b}}$ \\
E & $4.33 \pm 0.72^{\mathrm{a}}$ & $4.07 \pm 0.96^{\mathrm{a}}$ & $3.33 \pm 1.05^{\mathrm{a}}$ & $4.20 \pm 0.77^{\mathrm{a}}$ & $4.13 \pm 0.99^{\mathrm{a}}$ & $4.13 \pm 0.92^{\mathrm{a}}$ \\
F & $3.47 \pm 0.99^{\mathrm{c}}$ & $3.13 \pm 1.06^{\mathrm{a}}$ & $2.47 \pm 0.74^{\mathrm{a}}$ & $3.27 \pm 0.96^{\mathrm{c}}$ & $2.47 \pm 1.13^{\mathrm{c}}$ & $3.13 \pm 0.99^{\mathrm{b}}$ \\
G & $4.40 \pm 0.51^{\mathrm{a}}$ & $4.20 \pm 0.86^{\mathrm{a}}$ & $3.53 \pm 1.13^{\mathrm{a}}$ & $4.40 \pm 0.51^{\mathrm{a}}$ & $4.20 \pm 1.01^{\mathrm{a}}$ & $4.47 \pm 0.64^{\mathrm{a}}$ \\
\hline
\end{tabular}

Each value is the mean \pm standard deviation where $\mathrm{n}=15$ (number of people who participated in tasting wara). Means with different superscript within columns are significantly different at $\mathrm{p}<0.05$

Key to sample codes:

Sample A: Wara made from milk fermented with L. plantarum and L. acidophilus for 12 hours

Sample B: Wara made from milk fermented with Lactobacillus acidophilus for 24 hours

Sample C: Wara made from milk fermented with Lactobacillus acidophilus for 12 hours

Sample D: Wara made from milk fermented with Lactobacillus plantarum for 24 hours

Sample E: Wara made from milk fermented with Lactobacillus plantarum for 12 hours

Sample F: Wara made from milk fermented with L. acidophilus and L. plantarum for 24 hours

Sample G: Traditionally produced wara (control)

\section{DISCUSSION AND CONCLUSION}

The starter culture fermentation of milk by selected Lactobacillus species- single and mixed cultures for the production of wara was characterized by a decrease in $\mathrm{pH}$, an increase in TTA, diacetyl and lactic acid bacterial count throughout the fermentation period. This is similar to the results obtained by Ishola and Adebayo-Tayo (2012) and Akinkugbe and Oniude (2013) during the starter culture fermentation of milk by lactic acid bacteria. Zambou-Ngoufak et al. (2004) reported a decrease in $\mathrm{pH}$ with an increase in TTA during the starter culture fermentation of milk with Lactobacillus plantarum for the manufacture of kareish cheese. The increase in viable cell counts during fermentation is an indication that milk is a good substrate and the high amount of acid produced created a favourable medium for the growth of the lactic acid bacteria.

During the six days storage period of wara samples, a decrease in $\mathrm{pH}$ was observed with a corresponding increase in TTA. Effective inhibition of competing microorganisms depends on achieving the numbers of lactic acid bacteria sufficient to decrease the $\mathrm{pH}$ rapidly to levels where the growth of pathogens were prevented. Production of primary metabolite, such as lactic acid has been reported as the main preserving factor in food fermentation (Ogunbanwo et al., 2003; Adeyemo et al., 2018; Orike et al., 2018). Accelerated growth rate and metabolic activities of LAB have been reported to be responsible for the decrease in $\mathrm{pH}$ with fermentation time (Inyang and Idoko, 2006; Ajibola, 2017). A fast lowering of the $\mathrm{pH}$ to low levels and increase in titratable acidity has been reported to reduce the levels of contaminating microorganisms present on the raw materials, utensils and the environment (Holzapfel, 2002, Adeyemo et al., 2018; Orike et al., 2018). LAB may have produced other inhibitory products such as bacteriocins, diacetyl, volatile organic acids and hydrogen peroxide during fermentation. Although in this study, other inhibitory products such as hydrogen peroxide were not investigated, there is the likelihood that the organic acids and hydrogen peroxide produced during fermentation may be responsible for the lowering of the $\mathrm{pH}$. LAB have been known to produce these inihibitory susbstances during growth and metabolism (Adeyemo and Abimbola, 2019; Adeyemo and Bamidele, 2019). 
LAB was not detectable during the first three days of storage; this was however not a surprise; the curdling temperature for the production of wara$85^{\circ} \mathrm{C}$ for 10 mins is enough to kill the LAB cells inoculated as starter culture. According to Adetunji et al. (2007), a quality control point of wara cheese processing is the heating step at the curdling point that raises the temperature of milk to $95{ }^{\circ} \mathrm{C}$. At this point, the populations of total aerobes, enterobactericeae, psychrotrophs, mold and yeast decreased to the undetectable level. Adegoke et al. (1992) observed a similar decrease in the population of total aerobes at the pasteurization point during wara production .

The relatively lower $\mathrm{pH}$ and increased titratable acidity of wara produced with starter cultures may have contributed to the lower coliform and total bacteria counts compared to the higher levels observed in the traditionally-produced wara during storage. It is significant to note that wara produced with $L$. acidophilus fermented milk for 24 $\mathrm{h}$ had the least TCC (4.30 $\log _{10} \mathrm{CFU} / \mathrm{g}$ ) while the traditionally produced wara had the highest TCC (9.01 $\left.\log _{10} \mathrm{CFU} / \mathrm{g}\right)$. Also, wara produced from $\mathrm{L}$. acidophilus fermented milk for $12 \mathrm{~h}$ gave the least TBC count while the traditionally produced wara had the highest TBC counts during storage. This correlates with the result obtained in the screening procedure which points to the ability of Lactobacillus acidophilus to produce high amounts of hydrogen peroxide which is a strong antimicrobial metabolite (Ajibola, 2017; Adeyemo et al., 2018; Orike et al., 2018). During the storage of wara, signs of spoilage within 72 hours of storage, in the traditionally- produced wara, was noticed and manifested by a change in physical apperance such as aroma, colour and texture whereas the startermediated wara samples produced with lactic acid bacteria were still in good condition till the end of storage (144h).

The result of the organoleptic evaluation showed that wara made from milk fermented with mixed cultures of Lactobacillus plantarum and Lactobacillus acidophilus for 12 hours (sample A) and wara made from milk fermented with culture of Lactobacillus plantarum for 12 hours (sample E) were not significantly different from the traditionallyproduced wara $(G)$ in terms of general acceptability. This result is similar to the report by
Sanni et al. (1999) who reported that there was no significant difference in flavor and palatability between starter mediated wara and traditional wara. The result is however at variance with the report of Adesokan et al. (2009) and Akinkugbe and Onilude (2013) that starter- mediated wara were superior to traditional wara in terms of sensory properties.

Of the starter mediated wara samples, sample A (wara made from milk fermented with mixed cultures of Lactobacillus plantarum and Lactobacillus acidophilus for 12 hours) and sample E (wara made from milk fermented with Lactobacillus plantarum for 12 hours) were highly preferred by the panelists than other starter-mediated samples. This is an indication that Lactobacillus plantarum may have played a vital role in contributing to the development of these sensory attributes and that longer fermentation time has a negative impact on development of this sensory attributes (Adeyemo and Abimbola, 2019; Adeyemo and Bamidele, 2019).

The preference of starter-mediated wara sample from milk fermented with $L$. acidophilus and $L$. plantarum for $12 \mathrm{~h}$ over $24 \mathrm{~h}$ fermented milk may have been connected with the level of lactic acid and diacetyl in the samples. In this study, acidification of milk for $24 \mathrm{~h}$ by the starter cultures increased the level of TTA which probably increased the sourness of the product (Adeyemo et al., 2018; Orike et al., 2018). While diacetyl level in $24 \mathrm{~h}$ fermented milk probably got beyond the level which imparts positively on the flavour of wara. Excessive lactic acid in cheese has been reported to result in sourness (Hassan et al., 2003).

The selected starter cultures (Lactobacillus plantarum and Lactobacillus acidophilus) extended the shelf life of wara. It could be concluded that the selected starter cultures are suitable organisms to ferment milk for wara production. It is however recommended that further studies should be carried out on the optimization of the overall starter culture fermentation process for the production of wara with consistent quality and stability from batch to batch and possible scale up of the process. 


\section{REFERENCES}

Abdel, A., Abeer, A. A. and Dardir, H. A. (2009). Hygienic quality of local traditional fermented skimmed milk (Laban Rayb) sold in Egypt. World Journal of Dairy and Food Sciences, 4: 205-209.

Adegoke, G. O., Nse, E. N. and Akanni, A. O. (1992). Effects of heat, processing time, and $\mathrm{pH}$ on the microflora, aflatoxin content, and storability of wara, a soft white cheese. Die Nahrung, 36(3): 259-264.

Adeyemo, S.M., Awojobi, K.O, Ogunlusi, E.D. and Odediran, O.E. (2018). Biosynthesis of enzymes in fermented foods by lactic acid bacteria and its possible use as biopreservative in fermented milk. Journal of Advances in Biology and Biotechnology,19(3): 111.

Adeyemo, S.M. and Abimbola.O.G. (2019). Assessment of the nutritional qualities of a locally-produced weaning blend of sorghum 'Ogi' flour fortified with Bambara groundnut flour. The International Journal of Biotechnology, 8(2):115-124.

Adeyemo, S.M. and Bamidele, K.F. (2019). Effect of starter culture on anti-nutritional factors and shelf life of fermented smoked cassava (Pupuru): an African fermented staple. Nigerian Journal of Microbiology, 33(2):4668- 4777

Adesokan, I. A., Ekanola, Y. A., Fakorede, S. S., Oladejo, O. O. and Odutola, O. L. (2009). Influence of lactic starters on sensory properties and shelf life of wara-a Nigerian (unripened) soft cheese. Journal of Applied Biosciences,13: 714-719.

Adetunji, V.O., Alonge, D. O., Singh, R. K. and Chen, J. (2007). Production of wara, a West A frican soft cheese using lemon juice as a coagulant. Journal of Food Science and Technology,41(2):331-336.

Adeyemi, O.T., Mohammad, N.O., and Oladiji, A.T. (2012). Biochemical assessment of the Chrysophyllum albidum seed meal. African Journal of Food Science, 6(1): 20-28.

Ajibola, W. G. (2017) Assessment of the technological properties of lactic acid bacteria isolated from traditionally produced wara for the production of starter mediated wara. M.Sc. (Microbiology) Thesis, Obafemi
Awolowo University, Ile-Ife, Nigeria.

Akinkugbe and Onilude, A.A. (2013). Selective comparability and physiological studies of lactic acid bacteria protease and Calotropis procera (linn) eatracts. Peer J Journal Pre Prints $1: 141$ 1:e4v1.http://peerj.com/preprints/4 assessed 28/09/20

AOAC, (2000). Official Methods of Analysis. $15^{\text {th }}$ Edition. Association of Official Analytical Chemists, Virginia, U.S.A. pp 1141.

Ashaye, O. A., Taiwo, O. O. and Adegoke, G. O. (2006). Effect of local preservative (Aframomum danielli) in the chemical and sensory properties of stored waragashi. African Journal of Agricultural Research, 1(1): 10-16.

Bamidele, R. (2006). Developments and microbiological applications in African foods: emphasis on Nigerian wara cheese. M.Sc. Dissertation, Department of Applied Chemistry and Biology, University of Helsinki, Finland.

Chipah, S. K., Teye, M., Annor, J. A. and Teye, G. A. (2007). Potentials of Sodom apple (Calotropis procera) as a coagulant to substitute Alum in soy cheese production in Ghana, Food Science, 79: 30166-30170

Glantz, S. A. (1992). Primer of Biostatistics: The Program. Mc Graw-Hill Inc.

Hassan, A. N., Frank, J. F. and Elsoda, M. (2003). Observation of bacterial exopolysaccharide in dairy products using cryo-scanning electron microscopy. International Dairy Journal, 13: 755-762.

Holzapfel, W. H. (2002). Appropriate starter culture technologies for small-scale fermentation in developing countries. International Journal of Food Microbiology, 75:197-212.

Inyang, C. D. and Idoko, C. A. (2006). Assessment of the quality of Ogi made from matted millet. African Journal of Biotechnology, 5: 2334-2337

Ishola, R. O. and Adebayo-Tayo, B. C. (2012). Screening lactic acid bacteria isolated from fermented food for bio-molecules production. Australian Journal of Technology, 15(4): 205-217.

Ogunbanwo, S. T., Sanni A. I. and Onilude, A. A. (2003). Characterization of bacteriocin 
produced by Lactobacillus plantarum F1 and Lactobacillus brevis OG1. African Journal of Biotechnology, 2(8): 219-227.

Olukoya, D. K., Ebigwei, S. I., Olasupo, N. A. and Ogunjimi, A. A. (2011). Production of Dogik: An improved Ogi (Nigerian fermented weaning food) with potentials for use in diarrhoea control. Journal of Tropical Pediatrics, 40(2): 108 -113.

Orike, E.L., Adeyemo, S.M., and Omafuvbe, B.O. (2018). Probiotic potentials of lactic acid bacteria isolated from fermenting cassava. International Journal of Probiotics and Prebiotics, 13 (2/3): 69-76.

Oyewole, O. B. (1990). Optimization of cassava fermentation for fufu production $\mathrm{n}$ : Effects of single starter cultures. Journal of Applied Bacteriology 68: 49-54.

Sanni, A. I. Onilude, A. A. and Momoh, M.O. (1999). Selection of starters and starter mediated novel procedure for production of 'wara', a West African soft cheese. International Journal of Food Science and
Technology, 34: 325

Shah, N. P. (2000). Probiotic bacteria: selective enumeration and survival in dairy foods. Journal of DairyScience, 83: 894-907.

Shah, N. P. and Ravula, R. R. (2000). Microencapsulation of probiotic bacteria and their survival in frozen fermented dairy desserts. Australian Journal of Dairy Technology, 55: 139-144.

Teshome, G.(2015). Review of lactic acid bacteria function in milk fermentation and preservation. African Journal of Food Science,9(4):179-175:

Zambou-Ngoufak, F., Nour, E. A., MbianpoTchouanguep F. and El-Soda, M. (2004). Effect of ropy and capsular exopolysaccharides producing strain of Lactobacillus plantarum 162RM on characteristics and functionality of fermented milk and soft kareish type cheese. African Journal of Biotechnology, 3(10): 512-518. 